\title{
TICK AND TICK BORNE PROTOZOAN DISEASES OF LIVESTOCK IN THE SELECTED HILLY AREAS OF BANGLADESH
}

\author{
U.K. Mohanta ${ }^{*}$, Anisuzzaman² and M.M.H. Mondal ${ }^{3}$ \\ Received 31 October 2011, Revised 19 November 2011, Accepted 25 December, Published online 31 December 2011
}

\begin{abstract}
To study the tick and tick borne protozoan diseases of livestock in the hilly areas of Bangladesh, an attempt was made to collect tick and blood samples from cattle, goat and gayal (Bos frontalis) from different areas of the three hill districts. In this study, two species of ticks namely, Boophilus microplus (92\%) and Amblyomma testudinarium (21.6\%) and two species of blood protozoa like Babesia bigemina (16.63\%) and Anaplasma marginale (14.94\%) were recorded. Seasonal prevalence of ticks was highest in summer (97\%) in comparison to rainy (95\%) and winter (86\%) season. On the other hand, the seasonal prevalence of blood protozoa was highest in rainy season (45.45\%) in comparison to summer (27.87\%) and winter (16.55\%). Again, animals aged more than 2 (two) years of age (52\%) found to be more susceptible to blood protozoan diseases than animals aged between 1-2 years of age (33.97\%). But none of the animals under one year of age were found to be infected with blood protozoan diseases.
\end{abstract}

Key words: Tick, Blood Protozoa, Hilly Areas, Bangladesh

${ }^{1}$ Scientific Officer, Bangladesh Livestock Research Institute, Regional Station, Naikhongchari, Bandarban, Bangladesh; ${ }^{2}$ Department of Parasitology, Bangladesh Agricultural University, Mymensingh-2202, Bangladesh

*Corresponding author's email: uday_vet01@yahoo.com

Reviewed by Dr. S. M. Lutful Kabir, Bangladesh Agricultural University, Mymensingh, Bangladesh

\section{Introduction}

Bangladesh is a moderately hot and humid country with short winter and prolonged rainy season. The geo-climatic condition of Bangladesh is suitable for the development and survival of various parasites. Among the parasites, tick (ectoparasites) and endoparasites are very common. Tick is notorious ectoparasites which have wide host range and attacks various animals and birds. Many of them also attack man. They are voracious blood drinkers and all the developmental stages suck blood. Both male and female ticks are blood sucker. They continuously suck blood for long time, usually for 3-5 days (Kettle, 1995) resulting anaemia, malnutrition, and eventually reduce productivity. They damage skin and reduce the market value of hide and skin of livestock. Severely affected animals even may die (Soulsby, 1982). Besides, they transmit various deadly diseases caused by different types of organisms (Virus, Bacteria, Rickettsia, Protozoa etc.). Of them, tick acts as biological vector of some economically important protozoan diseases such as babesiosis, theileriosis and anaplasmosis, all of which affect livestock. These diseases are associated with various degree of morbidity and economic losses and even death may occur especially in untreated cases (Kettle, 1995). According to some local preliminary survey, Bangladesh is frequently affected by different species of ticks (Razzak and Shaikh, 1969; Qader and Huq, 1973; Rahman and Mondal, 1983). On the other hand, haemoprotozoan diseases of cattle have also been recorded from some districts of Bangladesh (Samad et al., 1983). But unfortunately, no attempt has yet been made to study the tick and tick borne diseases of livestock in the hilly areas of Bangladesh. Therefore, the research work was designed to study the prevalence, population density and hostpreference of ticks in the hilly areas of Bangladesh and the age and season related prevalence of haemoprotozoan diseases of livestock in the foresaid region.

\section{Materials and Methods}

About 1000 animals of different species (Gayal, cattle, sheep and goat) were selected randomly. Animals were examined by various methods of clinical examination such as distance inspection, close inspection etc. to detect the clinical signs, if any. The body coat was examined by imparting the hair against their natural direction and simultaneously close inspection was done to detect the tick infestation. 


\section{Collection and examination of ticks}

Ticks were examined by hand picking carefully so that mouth part remain intact. Collected ticks were kept in vials and necessary examination and identification were done in the laboratory according to the standard method (Cable, 1975) following the keys and description given by Soulsby (1982) and Wall and Shearer (1997). Internal organs of ticks were examined to detect developmental stages. For further clarification, when required, the samples were sent to the Department of Parasitology, Bangladesh Agricultural University for detailed description.

\section{Collection and examination of blood samples}

Blood sample were aseptically collected by needle from the jugular vein of the suspected animals and thin smears were produced. Smears were then air dried and fixed with methanol. Then the smears were stained by Giemsa's stain (Cable, 1957) and parasitic inclusions were identified according to the standard description (Soulsby, 1962; Lapage, 1962).

\section{Results and Discussion}

In this study, two species of ticks (Boophilus microplus and Amblyomma testudinarium) and two species of blood protozoa (Babesia bigemina and Anaplasma marginale) of livestock, viz. cattle (Bos indicus), goat (Capra hircus) and gayal (Bos frontalis) from various regions of the three hill districts (Bandarban, Rangamati and Khagrachari) of Bangladesh were recorded. Between the two tick species recorded in this study, B. microplus is widely distributed throughout the country but the distribution of $\mathrm{A}$. testudinarium is restricted to hilly areas. This distribution pattern of ticks has previously been reported by Mondal et al. (1995, 1996) and Islam et al. (1999, 2006). Dense vegetation in the hills with high rainfall above $3000 \mathrm{~mm}$ annually may have favored the distribution of A. testudinarium (Islam et al., 2006). Hoogstraal et al. (1972) pointed that highland forest might be the ideal habitat for A. testudinarium, since its distribution has been observed in the wooded environment from Ceylon and India to Borneo, Indonesia, Thailand, Vietnam, The Philippines, Taiwan and the southern islands of J apan.

To find out the population dynamics, overall prevalence and host preference of ticks, only the common livestock species like cattle, goat and gayal (endangered) from three hill districts were randomly examined in different seasons. The overall prevalence of B. microplus was 92\% whereas overall prevalence of A. testudinarium was only $21.6 \%$. The range of the tick population was 1-82 in case of B. microplus and 1-6 in case of A. testudinarium. Population density and host-preference of these ticks showed that B. microplus parasitized all the three species of livestock, viz. goat (100\%; 11.37 7.71$)$, gayal $(96.29 \%$; $8.73 \pm 7.41)$ and cattle (86.76\%; $9.20 \pm 10.93)$. But A. testudinarium mostly parasitized gayal $(70 \%$; $2.37 \pm 1.64)$ rather than goat (13.33\%; $1.75 \pm 1.5)$ and cattle (5.88\%; $2 \pm 1.41)$ (Table 1). The result indicates that B. microplus parasitisized a wide range of hosts while A. testudinarium may have a strong preference to a particular host (gayal), supporting that these ticks are not strictly host specific, although they might have a greater affinity for a particular host. This is supported by Harood and James (1979), who told that under natural conditions, a few tick species have shown a rather host-specificity while many others do not.

Table 1. Overall Prevalence, Population Density and Host-Preference of Ticks in the Hilly Areas of Bangladesh

\begin{tabular}{lccccc}
\hline \multicolumn{1}{c}{ Tick Species } & $\begin{array}{c}\text { Cattle } \\
(\%)\end{array}$ & $\begin{array}{c}\text { Goat } \\
(\%)\end{array}$ & $\begin{array}{c}\text { Gayal } \\
(\%)\end{array}$ & $\begin{array}{c}\text { No. of Ticks } \\
\text { Collected }\end{array}$ & $\begin{array}{c}\text { Overall } \\
\text { Prevalence } \\
(\%)\end{array}$ \\
\hline B. microplus & $\begin{array}{l}86.76 \\
(9.20 \pm 10.93)\end{array}$ & $\begin{array}{c}(11.37 \pm 7.71) \\
13.33\end{array}$ & $\begin{array}{c}96.29 \\
(8.73 \pm 7.41)\end{array}$ & 5555 & 92 \\
A. testudinarium & 5.88 & $(1.75 \pm 1.5)$ & $(2.37 \pm 1.64)$ & 300 & 21.6 \\
& $(2 \pm 1.41)$ & & & \\
\hline
\end{tabular}

Figures in the parentheses indicate mean \pm Standard deviation (Population Density).

Seasonal prevalence and population density of ticks was higher in summer (97\%; 9.63 \pm 12.02$)$ followed by rainy (95\%; 7.66 \pm 6.87$)$ and lower in winter (86\%; 7.21 \pm 6.42 ) (Table 2). It is assumed that hot and humid weather during the summer months (March-June) favors ticks building up to a high prevalence and density, while the winter months (November-February) may have an adverse effect on tick population because of dry and desiccating weather as there is little or no rainfall. These findings are in agreement with those of Rechav (1981), Short and Norval (1985) and Islam et al. (2006). 
Table 2. Seasonal Prevalence and Population Density of Ticks affecting Livestock in the Hilly Areas of Bangladesh

\begin{tabular}{|c|c|c|c|c|c|c|}
\hline \multirow[t]{3}{*}{ Tick Species } & \multicolumn{6}{|c|}{ Seasons } \\
\hline & $\begin{array}{l}\text { Summer (March- } \\
\text { J une) }\end{array}$ & & $\begin{array}{l}\text { Rainy (J uly- } \\
\text { October) }\end{array}$ & & $\begin{array}{l}\text { Winter } \\
\text { (November- } \\
\text { February) }\end{array}$ & \\
\hline & Prevalence & Density & Prevalence & Density & Prevalence & Density \\
\hline B. microplus & 95.55 & $11.07 \pm 12.74$ & 95.12 & $8.82 \pm 6.98$ & 84 & $8.82 \pm 6.49$ \\
\hline A. testudinarium & 17.77 & $2.78 \pm 2.11$ & 21.95 & $2 . \pm 1.19$ & 25 & $1.9 \pm 1.19$ \\
\hline Overall prevalence & 97 & $9.63 \pm 12.02$ & 95 & $7.66 \pm 6.87$ & 86 & $7.21 \pm 6.42$ \\
\hline
\end{tabular}

Prevalence is expressed as percentage. Density is expressed as mean \pm Standard deviation

For the study of blood protozoan diseases (Babesiosis and anaplasmosis) of livestock in the hilly areas of Bangladesh, peripheral blood smears of 625 animals of different age groups $(>2$ years, 1-2 years and $<1$ year) were randomly examined over a period of time from July,2007 to June,2008. Among 625 animals, 150 were goats where none was found to be infected with blood protozoan diseases. Of 475 animals (Cattle and Gayal) examined for blood protozoan diseases, $31.57 \%$ were positive. Among the infected animals, $16.63 \%$ were positive to babesiosis and $14.94 \%$ were positive to anaplasmosis.

Table 3. Seasonal Prevalence of Blood Protozoan Diseases of Livestock in the Hilly Areas of Bangladesh

\begin{tabular}{llllll}
\hline Seasons & $\begin{array}{l}\text { Prevalence(\%) } \\
\text { B. bigemina } \\
\text { Cattle }\end{array}$ & Gayal & $\begin{array}{l}\text { A. marginale } \\
\text { Cattle }\end{array}$ & \multicolumn{2}{c}{ Gayal } \\
& Cotal & \\
\hline Summer (March-June) & 20.83 & - & 7.11 & 2.22 & $27.87 \%$ \\
Rainy (J uly-October) & 28.33 & 2.44 & 15.12 & 2.44 & $45.45 \%$ \\
Winter (November-February) & 15 & - & 7.18 & - & $16.55 \%$ \\
Overall prevalence & 15.88 & 3.70 & 17.94 & 7.4 & \\
Total & $16.63 \%$ & & $14.94 \%$ & & \\
\hline
\end{tabular}

Prevalence of blood protozoan diseases was higher in rainy season (45.45\%) than that in the summer (27.87\%) and winter (16.55\%) (Table 3). This finding was similar to the study of Perez et al. (1994) and Mattioli et al. (1997) who recorded that rainy season is the most important factor in the prevalence of anaplasmosis and babesiosis. It is assumed that, due to the availability of green grasses in the rainy season, the animal maintain a good health and remain carrier state in endemic areas. On the other hand, tick population is high (95\%) at this time. This increased tick population may take part in disseminating the infection to the unexposed animal rendering high prevalence of blood protozoan diseases in the rainy season.

Table 4. Prevalence of Blood Protozoan Diseases of Livestock in Relation to different Age Groups

\begin{tabular}{|c|c|c|c|c|c|}
\hline Age group & No. of Animal Examined & No. of Animals infected & 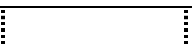 & Total & Percent Infected \\
\hline & & B. bigemina & A. marginale & & \\
\hline$>2$ years & 365 & 69 & 55 & 124 & 33.97 \\
\hline $1-2$ years & 50 & 10 & 16 & 26 & 52 \\
\hline <1year & '13\%"' & '"' & ':" & :"' & "'-"' \\
\hline
\end{tabular}

Prevalence of blood protozoan diseases was highest in cattle among the three species of animals in all seasons (Table 3). Among the three selected age groups, animals aged between 1-2 years were found more likely to be infected with blood protozoan diseases (52\%) than animals of more than 2 years of age (33.97\%). But none of the animals under 1 year of age were infected with blood protozoan diseases. It is assumed that aged animals are more susceptible to blood protozoan diseases than the younger animals-"inverse age resistance" (Urquhart et al., 1996). Similar results were obtained by Perez et al. (1994), who reported that the prevalence of blood protozoa was higher in animals aged over 1 year.

In case of babesiosis, clinical occurrence was only observed in plane areas surrounding the hilly areas. Although there is subclinical infections in animals of the hill, but there is no clinical outbreak. This may be due to the continuous tick challenge in hilly areas- "endemic stability" (Urquhart et al., 1996). 


\section{Conclusion}

In endemic areas where there is a continuous tick challenge, as in the hilly areas of Bangladesh, blood protozoan diseases is not a great problem if animals from infection free areas are not introduced. The problem is the massive tick infestation as they suck blood, give continuous irritation and cause mechanical injury to the skin along with the introduction of pathogenic bacteria, viruses, rickettsia and blood protozoa. Thus a strategy for controlling ticks of livestock in the hilly areas of Bangladesh needs to be established so that the infestation rate can be kept to a minimum level.

\section{References}

Harwood, R.F. and James, M.T. 1979. Entomology in human and animal health., $7^{\text {th }}$ edition (Macmillan, New York), $375 \mathrm{p}$.

Hoogstraal, H., Lim, B.L., Nadchatram, M., and Anastos, G. 1972. The Gunong Benom Expedition.8. Ticks (Ixodidae) of Gunong Benom and their Altitude distribution, hosts and medical relationships. Bulletin of the British Museum (Natural history), Zoology, London, 23: 67-186.

Huq, M.M. and Mollah, M.A. 1969. A survey on the prevalence of lice on sheep and goats of Dhaka and Mymensingh, East Pakistan, Pakistan J. Vet. Sci., 6(1-4): 21-25.

Islam, M.K. and Kibria, A.K.M.G., Majumder, S., Islam, M.F. and Mondal, M.M.H. 1999. Factors influencing Ixodid tick (Acari: Ixodidae) infestation of cattle in Bangladesh. Progr. Agric., 10: 131-135.

Islam, M.K., Alim, M.A., Tsuji, N. and Mondal, M.M.H. 2006. An investigation into the distribution , host-preference and population density of Ixodid ticks affecting domestic animals in Bangladesh. Tropical Animal Health Prod., 38: 485-490.

Kettle, D.S. 1995. Medical and Veterinary Entomology, 2 $2^{\text {nd }}$ edn. Colset Pte Ltd, Singapore.

Lapage, G. 1962. Veterinary Helminthology and Entomology. Bailliere Tindall and Cox Ltd. Fifth Edn. pp. 213-214.

Mattioli, R.C., Janneh, L., Corr, N., Faye, j.A., Pandey, V.S. and Verhulst, A. 1997. Seasonal prevalence of tick and tick transmitted haemoparasites in traditionally managed N'Dama cattle with reference to strategic tick control in the Gambia. Medical and Vet. Entomol., 11(4): 342-348.
Mondal, M.M.H., Giasuddin, M. and Islam, M.K. 1996. Amblyomma testudinarium (Acari: Ixodidae) infestation in Gayals (Bos frontalis) in Bangladesh. Proceedings of the 20th International Congress of Entomology, Florence, Italy, pp 63.

Mondal, M.M.H., Islam, M.K. and Kibria, A.K.M.G. 1995. Ecological studies on Hyalomma anatolicum anatolicum (Acari: Ixodidae) of cattle in Barind area in Bangladesh. Bangladesh Vet. J., 29: 63-66.

Perez, E., Herrero, M.V., Jimenez, C., Hird, G. and Buening, G.B. 1994. Effect of management and host factors on seroprevalence of bovine Anaplasmosis and Babesiosis in Costa Rica. Preventive Veterinary Medicine, 20(1-2): 33-46.

Qader, S.A. and Huq, M.M. 1973. A survey on the prevalence of ticks of sheep and goats in Commila Kotwali Police station, Bangladesh. M. Sc. (Vet. Sc.) Thesis, Bangladesh Agricultural University, Mymensingh.

Rahman, M.H. and Mondal, M.M.H. 1983. Tick fauna of Bangladesh. Abst. Sixth National Congr. Parasit. India, Pant. Nagar. Nov. 1984.

Razzak, A. and Shaikh, H. 1969. A Survey on the prevalence of ticks of cattle in East Pakistan. Pak. J. Vet. Sci., 3(2): 54-60.

Rechav, Y. 1981. Dynamics of tick population (Acari: Ixodidae) in Eastern Cave Province of South Africa. J. Med. Entomol., 19: 679700.

Samad, M.A., Dhar, S. and Gautam, O.P. 1983. Prevalence of Theileria annulata infection among cattle of Bangladesh. Indian. J. Parasit., 7 (1): 61-63.

Short, N.J. and Norval, R.A.I. 1985. Regulations of seasonal occurrence of ticks Rhipicephalus appendiculatus (Newman, 1901). Tropical Animal Health Production, 13: 19-26.

Soulsby, E.J.L. 1982. Helminths, Arthropod and Protozoa of Domesticated Animals, 7th edn. Bailliere Tindall, London, UK, 809 p.

Urquhart, G.M., Armour, J., Duncan, J.L., Dum, A.M. and Jennings, F.W. 1996. Veterinary Parasitology. $2^{\text {nd }}$ edition, Blackwell Science Ltd. London. pp. 242-243.

Wal, R. and Shearer, D. 1997. Veterinary Entomology, hapman and Hall, 2-6, Boundary Row, London SEI 8HN, UK. 